\title{
MAKING A LONG STORY SHORT: A NOTE ON MEN'S HEIGHT AND MORTALITY IN ENGLAND FROM THE FIRST THROUGH THE NINETEENTH CENTURIES
}

\author{
by \\ STEPHEN J. KUNITZ*
}

\section{INTRODUCTION}

For well over a century, it has been known that stature is related to nutrition. Only within the past decade, however, have historians begun to use data on heights as a measure of living standards and social class differences in past times, as well as to assess the degree to which improvements in nutrition contributed to the historic decline in mortality in Western Europe and North America. It is the latter issue with which I shall be most concerned in this paper.

The explanation of the remarkable decline in western European mortality in the eighteenth and nineteenth centuries has been a topic of some debate and has been attributed to prevention and/or therapy at the individual patient-practitioner level, public health improvements such as protection of food and water supplies and construction of sewer systems, less crowded housing, and better nutrition. The debate has considerable contemporary relevance, for in a period during which western governments are concerned with cost containment in health care, historic data showing that curative medicine played no role in the mortality decline in past times has been used to justify reduced expenditures in the present. Indeed, in two books published in 1976, Thomas McKeown has made explicit the relationship between historical inference and public policy. ${ }^{1}$

Though I am persuaded that smallpox vaccination had a profound impact on European mortality rates and patterns in the nineteenth century, I am not concerned here with the debate about the specific contribution of medical interventions. ${ }^{2}$ Rather, I am concerned primarily with the argument about the contribution of changing nutritional status. I take it as a reasonable series of inferences that nutrition has a significant (though not the only) influence on height; that nutritional status is related to susceptibility and resistance to many (but not all) infectious diseases; that average height of a population is a fair approximation of general nutritional status; and that therefore one should not be surprised to see a positive association between stature and

*S. J. Kunitz, MD, PhD, Department of Preventive, Family, and Rehabilitation Medicine, Box 644, University of Rochester Medical Center, 601 Elmwood Avenue, Rochester, NY 14642, USA.

${ }^{1}$ T. McKeown, The modern rise of population, New York, Academic Press, 1976; and The role of medicine, London, Nuffield Provincial Hospitals Trust, 1976. See also J. and S. McKinlay, 'The questionable contribution of medical measures to the decline of mortality in the United States in the twentieth century', $M M F Q /$ Health and Society, 1977, 55: 405-428.

2 A. J. Mercer, 'Smallpox and epidemiological-demographic change in Europe: the role of vaccination', Population Studies, 1985, 39: 287-307. J. H. Mielke, L. B. Jorde, P. G. Trapp, D. L. Anderton, K. Pitkanen, and A. W. Eriksson, 'Historical epidemiology in Aland, Finland: 1751-1890', Demography, 1984, 21: 271-295. 


\section{S. J. Kunitz}

life expectancy. Indeed, such an association has been observed in both historical and contemporary data. ${ }^{3}$ I shall suggest, however, that this association, though real, is not inevitable.

It is striking and not accidental that historical data on heights are almost invariably from institutionalized, "captive" populations-soldiers, orphans, schoolchildren, and slaves-and that they first become available in the eighteenth century. Statistics in its original meaning was "the science of the state", and it was in the eighteenth century that the modern state emerged in western Europe. Modernity implies, among other things, bureaucratized government agencies concerned with public health and the enumeration and control of the population, professionalized armies, and the integration of national and international markets. I have argued elsewhere that these developments contributed overwhelmingly to the decline of pandemics with their towering peaks of mortality that characterized the demographic regime of the early modern and pre-modern periods. ${ }^{4}$ Only after pandemics of plague were controlled by quarantine, and viral diseases such as measles and smallpox became childhood afflictions as a result of population growth and the integration of national economies (an eighteenth-century phenomenon) would one expect to see an association between nutritional status as reflected in mean heights and life expectancy. That is to say, the collection of vital statistics and the diminution in pandemics are both the effects of a common cause, the growth of states in the eighteenth century. This is not to suggest that pandemics and epidemics were the only causes of death in the pre-modern era. Rather, they were superimposed upon high levels of mortality from endemic diseases, and, as they they receded, endemic diseases (generally more responsive to living standards) emerged as relatively more significant than they had been previously.

How, then, may we discover data about height and mortality from earlier periods when the positive association between life expectancy and stature may not have existed? The logical source is skeletal material from archaeological sites.

\section{Archaeological Data}

There has been concern among historians regarding the sampling bias that may be introduced by using heights from institutionalized populations. ${ }^{5}$ When considering archaeological populations, the problem is at least as worrisome. The extent to which burials represent an unbiased sample of the social strata of a population living in a particular place at a particular time is generally unknown. The fact that some sites are excavated completely, others incompletely, and others not at all, obviously has an

${ }^{3}$ R. H. Steckel, 'Height and per capita income', Historical Methods, 1983, 16: 1-7. R. W. Fogel, 'Nutrition and the decline in mortality since 1700: some additional preliminary findings', working paper no. 1802, Cambridge, Mass., National Bureau of Economic Research, 1986. L. G. Sandberg and R. H. Steckel, 'Overpopulation and malnutrition rediscovered: hard times in 19th century Sweden', paper presented at the annual meeting of the Social Science History Association, Chicago, November 1985.

${ }^{4}$ S. J. Kunitz, 'Speculations on the European mortality decline', Econ. Hist. Rev., 2nd series, 1983, 36: $349-364$.

${ }^{5}$ R. W. Fogel, S. L. Engerman, R. Floud, G. Friedman, R. A. Margo, K. Sokoloff, R. H. Steckel, T. J. Trussell, G. Villaflor, and K. W. Wachter, 'Secular change in American and British stature and nutrition', Journal of Interdisciplinary History, 1983, 14: 445-81. 
important but unknown impact on the generalizations one may make. The preservation of skeletal material in some climates and soils and not others may result in bias. The fact that infants may not have been buried in cemeteries-particularly if infanticide was common-or their skeletons not preserved if they were, may result in significant underestimation of infant mortality.

Moreover, estimating height from skeletal remains is not as straightforward as it may appear. Commonly, skeletons are not complete. When they are incomplete and one attempts to estimate height from the lengths of various bones, one may be misled by genetic differences among racial groups. Among blacks, for instance, there is some evidence that legs contribute proportionately more to total height than among whites. ${ }^{6}$

The most common way to estimate height is with the regression formulae worked out by Trotter and Gleser ${ }^{7}$ using the lengths of long bones. The skeletal remains of American soldiers killed overseas during World War II and the Korean War were measured before reburial in the United States. Regressions were done using the length of long bones as the independent variable to predict ante-mortem measured height. Though there was considerable variability, it was possible to make reasonable predictions using just femur and tibia lengths, or femur alone. Different formulae were developed for white and black populations, and these are the ones most commonly used.

Determining sex using skeletal remains is also regarded as reasonably accurate, depending, of course, upon the completeness of the skeleton. ${ }^{8}$ It is age determination that is by far the most contentious issue. ${ }^{9}$ Because children may not have been buried in a cemetery, investigators often give estimates of average age at death only for adults. But even this is a problem because conventional techniques tend to underestimate the true age of the elderly. So contentious is this issue, indeed, that some pre-historians believe it is futile to attempt to estimate age at death from skeletal remains. Others have shown that, by using multiple indicators, age at death can be calculated with reasonable accuracy. ${ }^{10}$ Unfortunately, these newer techniques have not been applied to skeletal remains excavated many years ago, and estimates of age at death from such sites may thus be spuriously low.

Moreover, though chronic undernutrition may be reflected in short stature, evidence of acute famines is more difficult to detect. The stigmata used by palaeopathologistsgrowth arrest lines, for instance-are non-specific and may result from disease as well as famine. Porotic hyperostis is a useful indicator of anaemia, which, however, may be

\footnotetext{
6 J. M. Tanner, Foetus into man, London, Open Books, 1978, pp. 137-41.

${ }^{7}$ M. Trotter and G. C. Gleser, 'Estimation of stature from long bones of American whites and Negroes', American Journal of Physical Anthropology, 1952, 10: 463-514; and 'A re-evaluation of estimation of stature based on measurements of stature taken during life and of long bones after death', ibid., 1958, 16: 79-123.

${ }^{8}$ R. S. Meindl, C. O. Lovejoy, R. P. Mensforth, and L. Don Carlos, 'Accuracy and direction of error in the sexing of the skeleton: implications for paleodemography', ibid., 1985, 68: 79-85.

9 J.-P. Bocquet-Appel and C. Masset, 'Farewell to paleodemography', Journal of Human Evolution, 1982, 11: 321-333. J. E. Buikstra and L. W. Konigsberg, 'Paleodemography: critiques and controversies', American Anthropologist, 1985, 87: 316-333.

${ }^{10}$ R. S. Meindl, C. O. Lovejoy, and R. P. Mensforth, 'Skeletal age at death: accuracy of determination and implications for human demography', Human Biology, 1983, 55: 73-87. C. O. Lovejoy, R. S. Meindl, R.P. Mensforth, and T. J. Barton, 'Multifactorial determination of skeletal age at death: a method and blind tests of its accuracy'. American Journal of Physical Anthropology, 1985, 68: 1-14.
} 


\section{S. J. Kunitz}

caused by other factors than undernutrition. Unfortunately, the prevalence of such lesions is not available for the skeletal collections to be discussed here.

Yet another difficulty involved in the use of skeletal data is the relatively small number of specimens from rather long time periods. Short-term fluctuations in health status will inevitably be obscured as a result.

Despite the problems, analysis of archaeological material is one of the few ways, indeed probably the best way, to obtain estimates of height and life expectancy from past societies that did not keep the kinds of statistics that began to be increasingly common in the eighteenth century. In the following discussion, however, I shall not include age at death or estimates of life expectancy from archaeological populations, since many of the sites were dug before newer techniques of estimating age had become available, and the skeletons have almost certainly not been reanalysed. Thus an unknown amount of downward bias in age estimates is probably common. ${ }^{11}$

\section{RESULTS}

Figure 1 displays estimates of the population of England at fifty-year intervals pieced together from a number of sources. ${ }^{12}$ Several points are noteworthy. First, population grew very slowly until the mid-eleventh century, when the rate increased significantly following the Norman invasion. Only a little of this was from immigration: increased fertility following earlier age at marriage may have played an important role. ${ }^{13}$ Second, the crash in the second half of the fourteenth century that resulted from the plague pandemic reduced the population to a level from which it did not begin to recover until about two centuries later, i.e., the first half of the sixteenth century. Third, growth stabilized in the second half of the seventeenth century and only accelerated again in the second half of the eighteenth.

Figure 2 displays life expectancy at birth for every quinquennium from 1541 to 1901 for the total population, and in twenty-five year intervals for the peerage. ${ }^{14}$ Again, there are several points to which I wish to draw attention. First, there are three quite impressive downward spikes: in the $1550 \mathrm{~s}$, the $1680 \mathrm{~s}$, and the $1720 \mathrm{~s}$. It is not clear what caused them, but it is thought that in some instances famine may have been involved, in others a sequence of epidemic diseases. ${ }^{15}$ Second, the sawtoothed pattern of fluctuations in life expectancy, indicative of pandemics and epidemics, begins to moderate in the second half of the eighteenth century. Third, it was in the mid-eighteenth century that life expectancy at birth of British peers began to depart

\footnotetext{
${ }^{11}$ A. J. Nelson, 'A study of stature, sex and age ratios, and average age-at-death from the Romano-British to the late Anglo-Saxon period', unpublished MA thesis, Department of Archaeology and Prehistory, University of Sheffield, 1985.

12 Ibid. J. Hatcher, Plague, population and the English economy 1348-1530, London, Macmillan, 1977. E. A. Wrigley and R. S. Schofield, The population history of England 1541-1871, London, Edward Arnold, 1981.

${ }^{13}$ R. A. Donkin, 'Changes in the early middle ages', in H. C. Darby (editor), A new historical geography of England, Cambridge University Press, 1973, p. 76.

14 Wrigley and Schofield, op. cit., note 12 above, p. 230-231, provide data for the total population. The peerage life expectancies are from T. H. Hollingsworth, 'The demography of the British peerage', Population Studies, 1964, 18: Supplement, 56-57. I have averaged the life expectancies of males and females and plotted them at the mid-points of the 25-year intervals used by Hollingsworth.

${ }_{15}$ Wrigley and Schofield, op. cit., note 12 above, p. 668.
} 
FIGURE 1. POPULATION OF ENGLAND, 200-1900

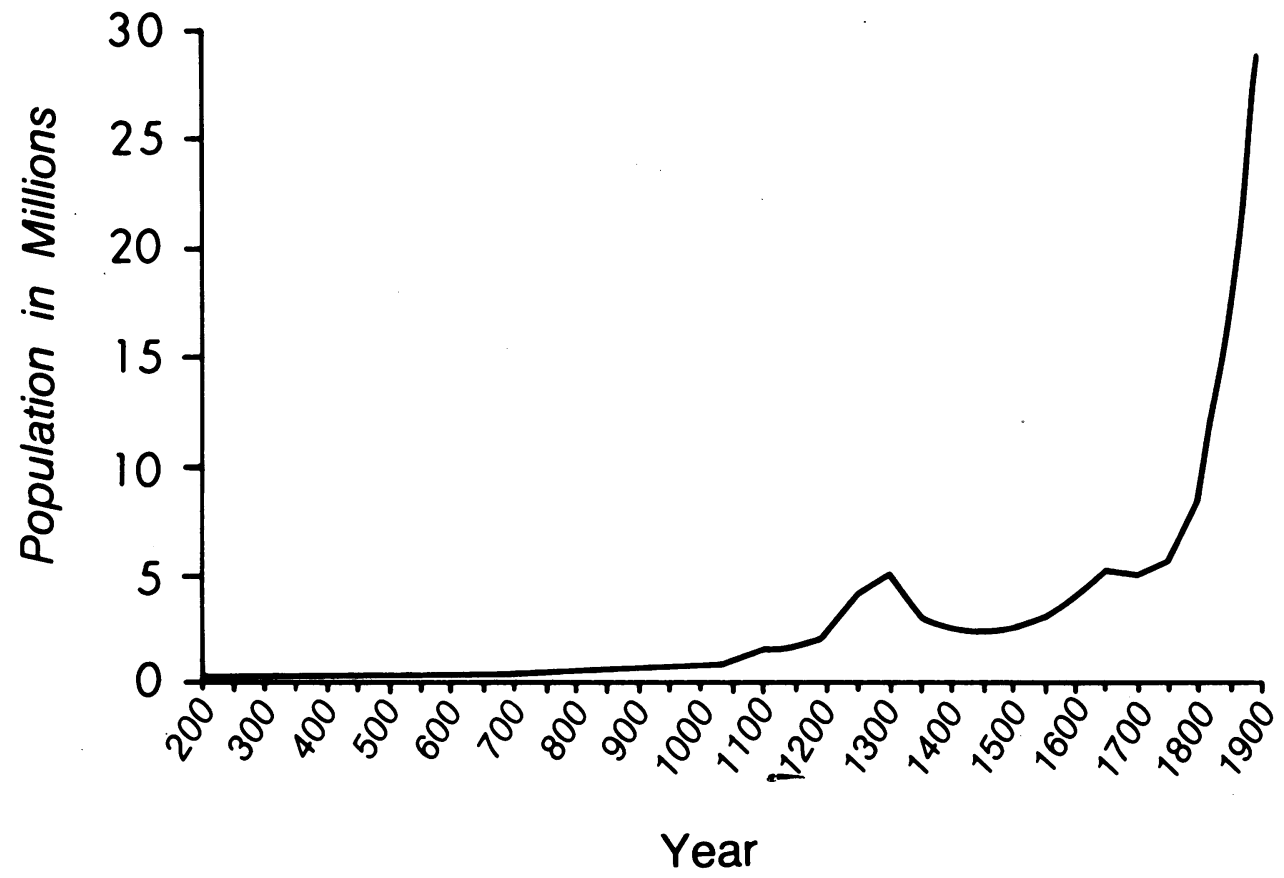

Sources: J. Hatcher, Plague, population and the English economy 1348-1530, London, Macmillan, 1977. A. J. Nelson, 'A study of stature, sex and age-at-death from the Romano-British to the late Anglo-Saxon period', unpublished MA thesis, Department of Archaeology and Prehistory, University of Sheffield, 1985. E. A. Wrigley and R. S. Schofield, The population history of England 1541-1871, London, Edward Arnold, 1981.

significantly from that of the total population, due to declining infant, child, and adult mortality. And fourth, sustained growth began as fluctuations in mortality diminished in the mid-1700s.

Now let us consider the data on heights displayed in Table 1. Notice first that height is relatively tall throughout the first millennium despite very slow, and in some instances negative, growth of population. Recall, however, the caveats regarding the use of archaeological data. Most importantly, it is not known from what social strata the skeletal remains come, and the samples are small and cover very long periods. Second, height was diminished at least as early as the mid-seventeenth century, and perhaps earlier, at the time when population was recovering from the declines of the fourteenth and fifteenth centuries. Third, the acceleration of population growth and the cessation of fluctuations in life expectancy, both of which began in the second half of the eighteenth century, preceded by more than half a century the beginning increase in heights, which seems to have occurred in the 1820s. Indeed, it was in the first several decades of the nineteenth century that height increased most dramatically until the 
FIGURE 2. LIFE EXPECTANCY AT BIRTH, 1541-1901

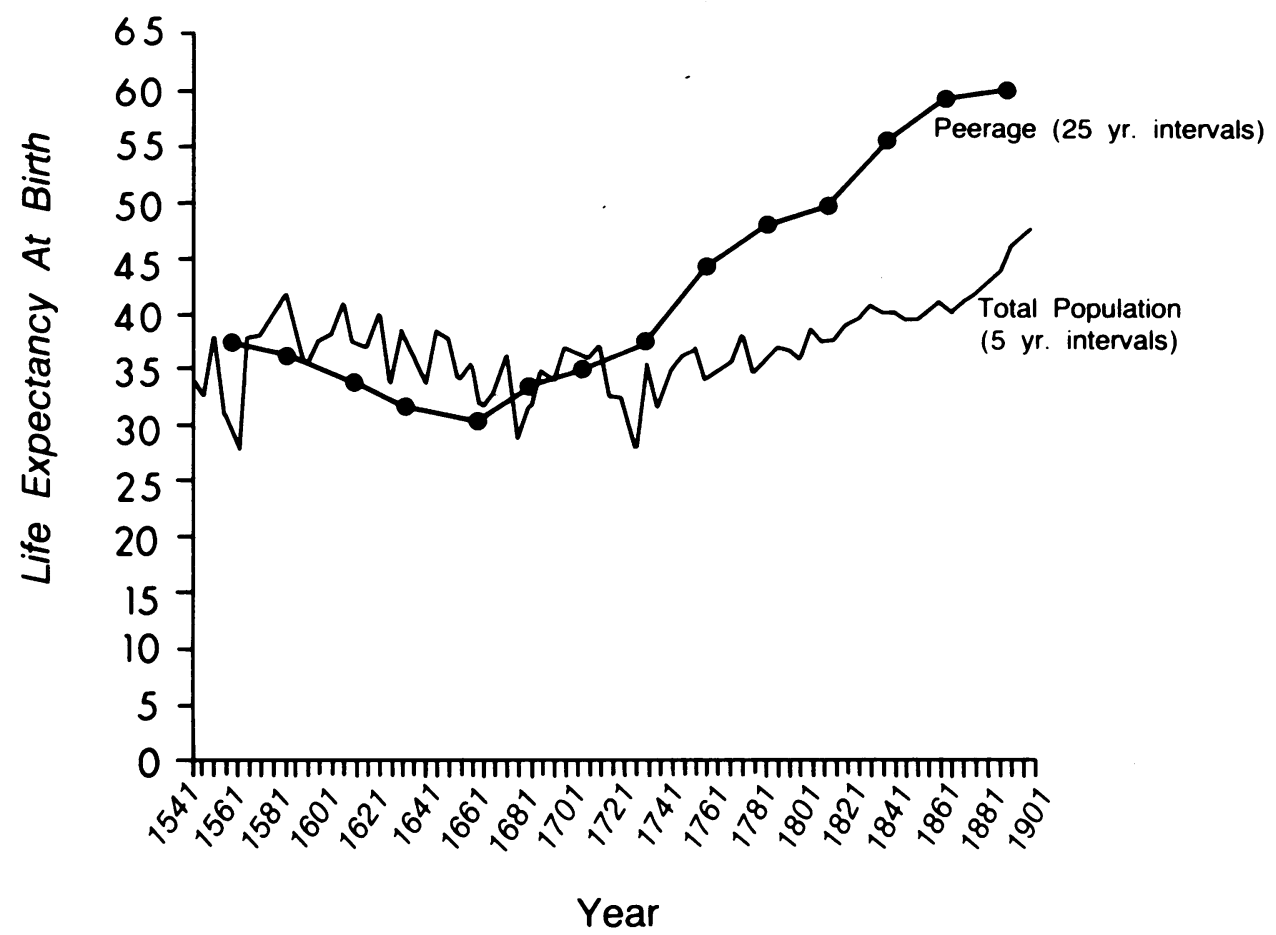

Sources: T. H. Hollingsworth, 'The demography of the British peerage, Population Studies, 1964, 18: Supplement, 56-57. E. A. Wrigley and R. S. Schofield, The population history of England 1541-1871, London, Edward Arnold, 1981.

twentieth century. ${ }^{16}$ The people whose height increased in the 1820 s were soldiers in their 20s, who would have been born around the turn of the century, fifty years after the changes in mortality began. Presumably, they were of lower-class origin, though the proportions coming from urban and rural areas is unknown. Despite the limitations of the data, the evidence suggests that epidemic mortality began to decline and population growth to accelerate two or three generations before the onset of nutritional improvement significant enough to influence height.

\section{Discussion}

The foregoing data raise several issues. Despite the lack of adequate estimates of life expectancy from the first millennium, it is reasonable to infer that the slow rate of population growth was the result primarily of high mortality rather than low fertility. Acute famines, several incursions of plague, and perhaps warfare probably caused many deaths. Despite what must be presumed to have been high mortality, the skeletal

${ }^{16}$ Fogel, op. cit., note 3 above, p. 89. 
TABLE 1: HEIGHTS OF ADULT MALES IN ENGLAND, FIRST THROUGH NINETEENTH CENTURIES

\begin{tabular}{|c|c|c|c|c|}
\hline Date (AD) & Height in $\mathrm{cm}$. & Number & s.d. & Type of data \\
\hline $43-407$ & $171 \cdot 1$ & 327 & $5 \cdot 23$ & archaeological (a) \\
\hline $450-650$ & $173 \cdot 3$ & 301 & 5.65 & archaeological (a) \\
\hline $650-850$ & $174 \cdot 0$ & 96 & $5 \cdot 20$ & archaeological (a) \\
\hline $850-1066$ & $171 \cdot 6$ & 78 & 5.93 & archaeological (a) \\
\hline $1200 s-1300 s$ & & & & \\
\hline $\begin{array}{l}\text { (English midlands) } \\
1650-1750\end{array}$ & $169 \cdot 6$ & 174 & & archaeological (b) \\
\hline (London) & $165 \cdot 5$ & 443 & & archaeological (b) \\
\hline *1762-75 & $171 \cdot 8$ & 36 & $4 \cdot 26$ & historical (c) \\
\hline *1776-82 & $170 \cdot 5$ & 75 & $4 \cdot 15$ & historical (c) \\
\hline $1776-82$ & $164 \cdot 3$ & 985 & & historical (d) \\
\hline *1783-89 & $171 \cdot 6$ & 56 & $5 \cdot 54$ & historical (c) \\
\hline $1790-99$ & 166.9 & 950 & $6 \cdot 82$ & historical (c) \\
\hline $1790 \mathrm{~s}$ & 167 & 6,073 & & historical (e) \\
\hline $1800 \mathrm{~s}$ & 164 & 7,055 & & historical (e) \\
\hline $1820 \mathrm{~s}$ & 169 & 10,523 & & historical (e) \\
\hline $1830 \mathrm{~s}$ & 173 & 10,863 & & historical (e) \\
\hline $1870 \mathrm{~s}$ & $170 \cdot 3$ & 43 & & archaeological (b) \\
\hline $1880 \mathrm{~s}$ & 171 & 1,948 & & historical (e) \\
\hline
\end{tabular}

Notes to Table 1

(a) A. J. Nelson, 'A study of stature, sex and age ratios and average age at death from the Romano-British to the late Anglo-Saxon period', unpublished MA thesis, University of Sheffield, 1985, and personal communication.

(b) N. M. Huber, 'The problem of stature increase: looking from the past to the present', in D. R. Brothwell (editor), The skeletal biology of earlier human populations, New York, Pergamon Press, 1968.

(c) A. T. Steegmann jun., 'Eighteenth century British military stature', Human Biology, 1985, 57: 77-95. (Heights not adjusted for truncation.)

(d) K. L. Sokoloff and G. C. Villaflor, 'The early achievement of modern stature in America', Social Science History, 1982, 6: 453-82. (Heights adjusted for truncation.)

(e) R. Floud, 'Two cultures? British and American heights in the nineteenth century, unpublished MS. (Heights adjusted for truncation.)

*Small sample sizes and lack of adjustment for truncation make these figures misleading

remains of adult males indicate average heights that were the same as those achieved in the nineteenth century. With such small numbers, it is hard to know how much significance to attach to the decline from the seventh/ninth centuries to the thirteenth/fourteenth centuries. It is at least compatible with what is known of dietary patterns ${ }^{17}$ and the occurrence of famines in the century preceding the Black Death. ${ }^{18}$

In respect of the two centuries following the Black Death, John Hatcher ${ }^{19}$ has shown that population continued to decline and remained low from 1348 to about 1520 , at a time when real wages were higher and food more plentiful than before or after. The only adequate explanation, he argues, is that low population meant higher per capita

${ }^{17}$ C. Dyer, 'English diet in the later middle ages', in T. H. Aston, P. R. Cross, C. Dyer, and J. Thirsk (editors), Social relations and ideas, Cambridge University Press, 1983.

18 Donkin, op. cit., note 13 above, p. 78.

${ }^{19}$ Hatcher, op. cit., note 12 above, p. 71 . 


\section{S. J. Kunitz}

food consumption and incomes, and low population was the result of mortality from causes that were insensitive to nutritional status. ${ }^{20}$

The height data indicate that some time between the 1300 s and 1600 s stature reached a nadir from which it did not recover until the nineteenth century. Unfortunately, I have not found archaeological data for the period when the decrease occurred, but I would speculate that it was in the early 1500 s when population began to increase and real wages began to decline. ${ }^{21}$ The growth of population could well have resulted in the depression of wages and per capita food consumption and thus in diminished stature. If this is the case, then the situation may have been analogous to that which seems to have occurred between the eleventh and thirteenth centuries. In both instances, increasing population seems to have been accompanied by decreasing height.

This Malthusian system persisted in modified form over the next three centuries, from the early 1500 s through the late 1700 s. Population grew as a result of both increased fertility and decreased mortality, but stature remained shorter than it ever had been previously or ever has been subsequently. Unfortunately, height data are too sparse in this period to be related to fluctuations in prices and wages. The question with which I am concerned is, why did mortality begin to decline in a population showing more evidence of chronic under-nutrition than has ever been seen in England before or since?

The answer has to do, I believe, with two related phenomena: (1) some of the most important infectious causes of death were not made significantly more lethal by the malnourished state of the population and receded for reasons unrelated to nutrition; and (2) the increasing integration of the English economy meant that after the mid-seventeenth century, acute famines ceased to be a major cause of death, though undernutrition persisted.

In respect of the identifiable infectious diseases, plague, typhus, smallpox, the "sweating sickness", dysentery, and influenza are generally considered to have been most significant. ${ }^{22} \mathrm{~A}$ recent effort to assess the nutritional influence on outcomes of infections ${ }^{23}$ suggests that smallpox and plague are not particularly responsive to nutritional status; typhus and influenza have an equivocal or variable relationship; and the diarrhoeas are definitely associated with nutrition, though there is reason to believe that diarrhoea in infants and children may be more important as a cause of malnutrition and stunting than malnutrition is as a cause of diarrhoea. ${ }^{24}$ The sweating

\footnotetext{
${ }^{20}$ Roger Schofield in a personal communication has expressed scepticism that zero population growth in this period was due entirely to high mortality. "The problem is that if we suppose that fertility had been invariant at the mid-sixteenth-century levels, as first observed in the parish register data, so that all the acceleration from zero to $\mathbf{0 . 7 5 \%}$ growth-rate by the late sixteenth century had been due to a shift in mortality, then the average long run expectation of life at birth in the middle ages would have had to have been no higher than 25 years in order to have secured zero population growth rate. This is possible, but seems to me to be unlikely."

${ }^{21}$ Hatcher, op. cit., note 12 above, p. 71.

22 A. B. Appleby, 'Disease or famine? mortality in Cumberland and Westmorland', Econ. Hist. Rev., 2nd series, 1973, 26: 403-431, p. 423.

${ }^{23}$ Conference participants, 'The relationship of nutrition, disease, and social conditions: a graphical presentation', Journal of Interdisciplinary History, 1983, 14: 503-506, p. 506.

${ }^{24}$ R. Martorell and T. J. Ho, 'Malnutrition, morbidity, and mortality', in W. H. Mosley and L. C. Chen (editors), Child survival: strategies for research, Cambridge University Press, 1984.
} 


\section{Making a long story short}

sickness, which may have been caused by an arbovirus enzootic in Eastern Europe, seems not to have been made worse by poor nutritional status, and in fact seems to have been most lethal among the upper classes. ${ }^{25}$

I have suggested elsewhere that plague disappeared from England in the lateseventeenth century largely as a result of improvements in quarantine, and that smallpox declined in the eighteenth century as a result of population growth and improved communications which converted it increasingly into a childhood disease. ${ }^{26}$ With regard to the recession of plague, there is no universally accepted explanation. Human intervention seems to me most likely. The timing of the last outbreaks, earliest in western Europe and later in the East, seems more closely related to local efforts at quarantine in the seventeenth century and national efforts in the eighteenth than to growing immunity to the causal agent of either the human or rodent populations. ${ }^{27}$

With regard to smallpox, the fact that it is a viral disease which causes permanent immunity in those who survive it means that it cannot be maintained in small, isolated populations. Thus, like other diseases with these same characteristics (polio, measles), there may be intervals of many years between epidemics in small populations. When the virus is reintroduced, it affects all those born since the previous epidemic, including, of course, adults, and results in high mortality not only because the disease itself is virulent but because adults-the usual care-givers-also fall ill. Thus networks of social support may collapse. In large populations into which many new susceptibles are born each year, therefore, these diseases increasingly afflict children. That, in fact, is what occurred in the case of both measles and smallpox in the course of the eighteenth century, a time when not only was population growing but, as I shall indicate below, the national economy was becoming more and more integrated and communication within the country expanding. ${ }^{28}$

There is little reason to believe that dysentery and influenza became less significant. Typhus probably did, as armies became more professionalized, military hygiene improved, and famines diminished. The cause of the disappearance of the sweating sickness, like its origin, remains a mystery. Thus the two major epidemic diseases that were not responsive to nutritional status seem to have disappeared or declined significantly as a result of either state intervention or the growth and integration of the population.

In respect of acute famines, it has been suggested that prior to the mid-seventeenth century, there were two Englands; one in the pastoral North, remote and susceptible to harvest failure and the incursion of periodic epidemics afflicting isolated, virgin soil populations; the other in the South, engaged in arable agriculture, with a high degree of occupational specialization, easy access to grain, and dense networks of

${ }^{25}$ J. A. H. Wylie and L. H. Collier, 'The English sweating sickness (Sudor Anglicus): a reappraisal', J. Hist. Med., 1981, 36: 425-445.

${ }^{26}$ Kunitz, op. cit., note 4 above.

${ }^{27}$ P. Slack, 'The disappearance of plague: an alternative view', Econ. Hist. Rev., 2nd series, 1981, 33: 469-476, and The impact of plague in Tudor and Stuart England, London, Routledge \& Kegan Paul, 1985, ch. 11 .

${ }^{28} \mathrm{Kunitz}$, op. cit., note 4 above, p. 354. Whether inoculation in the eighteenth century had a significant impact on mortality decline from smallpox is still a contentious issue. D. R. Hopkins, Princes and peasants: smallpox in history, University of Chicago Press, 1983, pp. 76-77. 


\section{S. J. Kunitz}

communication. Dense networks facilitated the spread of disease while access to grain protected against famine. By the late seventeenth century, these distinctions had disappeared as the two regions became increasingly integrated, and as "agricultural practices changed, market networks developed, and the geographical centre of gravity of industry and population began to move towards the North."29 Thus the breakdown of isolation seems to have meant that the North was no longer subject to famine as it had been previously. Judging by the height data, however, famines may have been averted even as chronic under-nutrition persisted, not an uncommon phenomenon among the populations of less developed countries at present.

Moreover, Robert Fogel has suggested that, "After c. 1400 or c. 1500, famines in England were rare events, affecting a minority of the population, and accounting for a miniscule proportion of accumulated deaths." He goes on to say that, "What is known about the course of agricultural production suggests that until the end of the Napoleonic Wars, English laborers were about as badly fed as the lower classes in such countries as India, Pakistan, and Bangladesh shortly after World War II. This conclusion is consistent with the currently available data on the heights of English laborers between 1760 and 1810. The impact of chronic malnutrition on English mortality rates during the pre-industrial era remains an open issue." 30

There has been much written about the timing of the agricultural revolution in England. Overton has shown that wheat production per acre about doubled from the late-sixteenth to the early-eighteenth century, and doubled again from the mideighteenth to some time in the first half of the nineteenth century. ${ }^{31}$ During the same period, as we have seen, population increased as well. Whether agricultural improvement was the response to population pressure as Boserup's ${ }^{32}$ hypothesis suggests, or population growth was the result of agricultural innovations as the conventional wisdom would indicate, or whether both are true, are issues beyond the bounds of my subject. What is clear from the height data is that food production for the 200 years from the late-sixteenth to the late-eighteenth centuries was able to sustain the population at levels compatible with fertility high enough for numbers to grow even in the face of both stunting of growth at young ages and high mortality. That is to say no more than that even little people may be fruitful and fill the earth, as is happening in less developed nations at present.

What is important for my purposes, however, is that mortality began to decline at least half a century before the height data indicate a significant improvement in nutrition. I have argued that this supports the notion that in its earliest phase the mortality transition was not related so much to improved nutritional status as to the decline of diseases that were responsive to other forces. ${ }^{33}$ It is in this connexion that the

\footnotetext{
${ }^{29}$ Appleby, op. cit., note 22 above. Wrigley and Schofield, op. cit., note 12 above, pp. 677-685.

${ }^{30}$ Fogel, op. cit., note 3 above, pp. 86-87.

${ }^{31} \mathrm{M}$. Overton, 'Agricultural revolution? Development of the agrarian economy in early modern England', in A. H. Baker and D. Gregory (editors), Explorations in historical geography, Cambridge University Press, 1984, p. 133.

${ }^{32}$ E. Boserup, The conditions of agricultural growth, Chicago, Aldine, 1965; and Population and technology, Oxford, Blackwells, 1981.

${ }^{33}$ Kenneth Kiple has suggested to me that the introduction of potatoes was significant in the diet of the poor wherever it was introduced. In England, however, "It was only during harvest failures in the
} 
divergence of life expectancy of the peerage and the rest of the population is significant, for it occurred at just the time that the wide swings in life expectancy of the latter were diminishing. I believe this may indicate that once pandemics were reduced by the mid-eighteenth century, the better living conditions, dietary practices, and nutritional status of the peerage began to have a profound impact on their life expectancy at all ages. ${ }^{34}$ It was only in the early-nineteenth century that nutritional status and living conditions of the mass of the population began to improve sufficiently that their life expectancy began an upward movement as well.

By the early-nineteenth century, then, a true revolution had occurred. Population was growing not only in number but in stature, for even as Malthus was writing, the system to which we have attached his name was being overturned. No longer was population growth accompanied by impoverishment and undernutrition. Indeed, it was at this time that the association between population growth and rising commodity prices was broken.$^{35}$ Now for the first time a different sort of cycle was established: population growth was accompanied by improving rather than worsening nutritional status, which, in turn, reduced mortality even further. This could happen because for the first time diseases sensitive to nutritional status were the most significant determinants of mortality. With the recession of plague, smallpox and typhus, tuberculosis, pneumonias, and diarrhoeas-the latter three all responsive to nutritional status-assumed greater relative significance. ${ }^{36}$ Earlier when other causes prevailed, and later when nutritionally sensitive diseases had largely receded, nutritional status was not as powerful a predictor of mortality as it was during the nineteenth century, or as it still is among many populations in less developed nations. ${ }^{37}$

Napoleonic Wars that it [the potato] began to be grown as a food crop." D. B. Grigg, Population growth and agrarian change, Cambridge University Press, 1980, p. 178. Kiple has also suggested that the use of corn (introduced from the Americas) for fodder improved cattle feeding, allowing farmers to avoid autumn butchering. The development of an improved meat and dairying industry may then have provided more high-quality protein for the population, thus aiding survival even if children were not fed sufficient amounts to increase their adult stature. Improved access to milk seems to have been a late-eighteenth-century phenomenon as well. M. W. Beaver, 'Population, infant mortality, and milk', Population Studies, 1973, 27: 423-454. I have pointed out elsewhere that this seems to me a reasonably significant contributing cause of improved infant mortality, but just how significant is by no means clear. Kunitz, op. cit., note 4 above, p. 360.

${ }^{34}$ I have not found height data from the eighteenth century which distinguishes among social classes. Nineteenth-century data on heights of fourteen- and fifteen-year-old working-class and aristocratic boys indicate substantial differences, however. In the first decade of the century, the latter were on average about $9 \mathrm{~cm}$. 3.5 inches) taller than the former. The differences had narrowed to $6-7 \mathrm{~cm}$. by the $1840 \mathrm{~s}$. Very likely, the differences were at least as great in the previous century. R. Floud, 'Measuring the transformation of European economies: income, health and welfare', Discussion paper no. 33, London, Centre for Economic Policy Research, 1984.

35 Wrigley and Schofield, op. cit., note 12 above, p. 403.

36 The picture is complicated by the fact noted previously, that there is at least as much evidence that childhood diarrhoea is a cause of malnutrition and stunting as there is that malnutrition causes diarrhoea. (Malnutrition may increase the risk of death from an episode of diarrhoea but does not necessarily increase the incidence of diarrhoea.) Thus, measures that reduced the incidence of diarrhoea may well have had an impact on adult stature. Among them may have been both public health interventions such as protected water and food supplies, and changes in individual behaviour such as improved personal hygiene and breast-feeding.

${ }^{37}$ I have addressed this issue in more detail in 'Mortality since Malthus', in D. Coleman and R. Schofield (editors), The state of population theory: forward from Malthus, Oxford, Blackwells, 1986. 


\section{S. J. Kunitz}

That is to say, until the turn of the nineteenth century, the dominant pattern of mortality was largely independent of wages, the price of food, and nutritional status. When an association did become evident, it was because certain infectious diseases had declined, most likely because human intervention and social organization had become effective rather than as a result of the evolution of a hardy stock by natural selection.

There are several reasons why these observations are worth reporting, aside from their very considerable intrinsic interest, of course. They serve to emphasize once again what a remarkable change occurred in England - and presumably western Europe-at the turn of the nineteenth century. They also remind us that one explanation may not cover all cases, and thus they encourage caution in invoking historical arguments in support of contemporary public policies. In some instances, stable governments able to enforce minimal public health measures may be sufficient to reduce mortality substantially. At other times, more food may be what is required. And in some situations medical technology, either preventive or curative, may be appropriate. History should inform the choice, not determine or rationalize it.

\section{ACKNOWLEDGEMENTS}

Stanley Engerman, John Hatcher, Kenneth Kiple, Andrew J. Nelson, Roger Schofield, E. Carol Stein, and Alan Swedlund commented on an early draft of this paper. Roderick Floud, Ann Grauer, and Andrew Nelson have made available unpublished data. Richard Meindl provided useful information on the analysis of skeletal remains. 